\title{
Analisis Faktor-Faktor yang Mempengaruhi Urban Spraw/di Kawasan Cekungan Bandung
}

\author{
Analysis of Factors that Influence Urban Sprawl di Bandung Metropolitan Area \\ Lutfia Nursetya Fuadina ${ }^{1}$, Ernan Rustiadi ${ }^{2}$ dan Andrea Emma Pravitasari²
}

Diterima: 27 Agustus 2018

Disetujui: 4 Januari 2021

\begin{abstract}
Abstrak: Kawasan Cekungan Bandung merupakan kawasan metropolitan dengan jumlah populasi terbanyak kedua di Indonesia setelah Metropolitan Jakarta. Kawasan Cekungan Bandung juga dapat merepresentasikan metropolitan di Asia yang memiliki karakteristik urbanisasi yang masif disebabkan oleh pertumbuhan ekonomi yang terus meningkat. Penelitian ini bertujuan untuk menganalisis keragaman spasial faktor-faktor yang mempengaruhi peningkatan luas lahan terbangun di Kawasan Cekungan Bandung. Data yang digunakan dalam penelitian ini adalah data sekunder yang terdiri dari citra satelit Landsat dan data fasilitas yang diperoleh dari Badan Pusat Statistik (BPS) pada tahun 2003 dan 2014. Metodologi yang digunakan dalam penelitian ini adalah analisis Geographically Weighted Regression (GWR). Hasil analisis GWR menunjukkan bahwa masing-masing variabel memberikan pengaruh yang berbeda di masing-masing lokasi. Variabel kepadatan penduduk berpengaruh positif terhadap peningkatan persentase luas lahan terbangun. Variabel jarak ke Kota Bandung, persentase luas sawah, persentase luas hutan, jarak ke jalan tol berpengaruh negatif terhadap peningkatan persentase luas lahan terbangun. Sedangkan pengaruh variabel IPK terhadap peningkatan persentase luas lahan terbangun bervariasi di setiap lokasi penelitian.
\end{abstract}

Kata kunci: Geographically Weighted Regression, pertumbuhan ekonomi, perubahan penggunaan lahan

\begin{abstract}
Bandung Metropolitan Area is the second largest metropolitan area in Indonesia. Bandung Metropolitan Area also represents the type of metropolitan in Asia which has massive urbanization characteristic that caused by increasing economic growth. This research aims to analyze the spatial diversity of the factors influencing urban sprawl in Bandung Metropolitan Area. The data used in this study were secondary data consisting of Landsat satellite imagery and facilities data obtained from the Central Statistics Agency (BPS) in the year of 2003 and 2014. The methodology used in this study was Geograpically Weighted Regression (GWR) analysis. The results showed that each variables has a different influence on each locations. Population density variable has a positive effect on the percentage of built up area. Whereas the variable of distance to Bandung City, the percentage of paddy field area, the percentage of forest area, and the distance to the toll road has a negative effect on the percentage of built up area. While the effect of the District Development Index variable toward the percentage of built up area varies in each research location.
\end{abstract}

Keywords: economic growth, Geographically Weighted Regression, land use change

\footnotetext{
${ }^{1}$ Program Magister Perencanaan Wilayah, Fakultas Pertanian, IPB

${ }^{2}$ Departemen Ilmu Tanah dan Sumberdaya Lahan, Fakultas Pertanian, IPB
} 


\section{PENDAHULUAN}

Metropolitan-metropolitan utama di negara-negara kawasan Asia-Pasifik telah mengalami perubahan masif selama dua hingga tiga dekade terakhir yang disebabkan oleh urbanisasi. Penyebab urbanisasi bervariasi pada negara-negara yang berbeda, tetapi secara umum dapat dikatakan sebagai hasil dari ketidakseimbangan spasial, termasuk penduduk dan ketidakseimbangan ekonomi. Urbanisasi umumnya terkait dengan sejumlah masalah sosial, ekonomi dan permukiman di daerah perkotaan dan perdesaan (Rustiadi et. al 2009). Negara berkembang telah mengalami urbanisasi sejak tahun 1950 sebagai konsekuensi dari suatu tatanan ekonomi baru yang dihasilkan dari reorganisasi produksi, tenaga kerja, keuangan, penyediaan layanan dan persaingan secara transnasional yang ditandai dengan pertumbuhan penduduk di pusat metropolitan (Clark 1998). Indonesia, seperti halnya negara-negara berkembang lainnya, sedang mengalami pertumbuhan perkotaan yang pesat. Berdasarkan laporan dari United Nation (2016), pada tahun 2016, diperkirakan 54,5 persen dari populasi dunia tinggal di permukiman perkotaan. Pada tahun 2030, daerah perkotaan diproyeksikan menjadi rumah bagi 60 persen orang di seluruh dunia, dan satu dari setiap tiga orang akan tinggal di kota-kota dengan setidaknya sejumlah setengah juta penduduk. Di Indonesia sendiri, selain Metropolitan Jakarta, kota-kota metropolitan lainnya juga mempunyai peran strategis dalam pembangunan wilayah sebagai pusat kegiatan ekonomi yang mempunyai hubungan ke belakang dengan kota-kota hinterlandnya, salah satunya adalah di Bandung Metropolitan Area (BMA) atau juga biasa disebut Kawasan Cekungan Bandung maupun Bandung Raya.

Metropolitan Bandung merupakan kawasan metropolitan dengan jumlah populasi terbanyak ketiga di Indonesia setelah Metropolitan Jakarta dan Metropolitan Surabaya dengan jumlah populasi lebih dari 8,5 juta pada tahun 2015. Dua wilayah metropolitan yaitu Metropolitan Jakarta (Jabodetabek) dan Bandung Raya mengalami fenomena ekspansi perkotaan. Metropolitan Jabodetabek dan Metropolitan Bandung menjadi semakin terhubung untuk menjadi daerah mega-urban melalui koridor perkotaan, yang membentang dari Serang ke Cikampek, dan dari Bandung ke Jakarta sehingga disebut Jakarta-Bandung Mega-Urban Region atau JBMUR (Firman dan Dharmapatni 1995). Metropolitan Bandung meliputi wilayah administrasi Kota Bandung, Kabupaten Bandung, Kabupaten Bandung Barat, Kota Cimahi, dan 4 kecamatan yang terdiri dari Kecamatan Jatinangor; Kecamatan Cimanggung; Kecamatan Tanjungsari; dan Kecamatan Sukasari di Kabupaten Sumedang. Kawasan tersebut ditetapkan dalam Rencana Tata Ruang Wilayah Nasional (RTRWN) sebagai Kawasan Strategis Nasional (KSN) dalam aspek ekonomi yang tercantum dalam Peraturan Presiden Nomor 26 Tahun 2008.

Metropolitan Bandung disiapkan untuk menjadi functional linkages dengan infrastruktur yang terintegrasi dan memungkinkan untuk terbukanya kerjasama kota dengan kota maupun kota dengan level kabupaten dalam sektor industri, ekonomi, dan jasa (Tarigan et al. 2016). Berdasarkan hal tersebut maka selain memiliki daya tarik berupa urban tourism, Metropolitan Bandung juga dapat merepresentasikan metropolitan di Asia yang memiliki karakteristik urbanisasi yang masif yang disebabkan pertumbuhan penduduk. United Nation (2013) menyebutkan bahwa pada tahun 2010, populasi perkotaan kawasan Asia-Pasifik berjumlah 754 juta orang, yang lebih dari gabungan populasi Amerika Serikat dan Uni Eropa. Saat ini hampir setengah dari populasi, yaitu 45,5 persen di wilayah tersebut tinggal di daerah perkotaan.

Seiring dengan pertumbuhan penduduk yang berpengaruh terhadap tingkat perkembangan suatu wilayah, maka semakin intensif pula perubahan penggunaan lahan khususnya untuk kebutuhan tempat tinggal. Firman (2009) menunjukkan selama periode 1994-2001 terjadi penurunan luasan wilayah hutan primer $(2,7 \%)$ dan hutan sekunder $(85,9 \%)$, sawah (19\%), kebun campuran dan perkebunan (34\%) di Metropolitan Bandung. 
Selanjutnya apabila perkembangan wilayah tersebut tidak dapat dikendalikan maka akan berakibat negatif terhadap perkembangan fisik perkotaan seperti terjadinya urban sprawl. Kondisi sprawl menjadi tidak terkendali karena urbanisasi dipandang menjadi suatu tren namun berakibat malapetaka karena terjadi lebih banyak konversi lahan dari lahan pertanian menjadi lahan non pertanian, semakin meningkatnya pengangguran dan kemiskinan, serta degradasi lingkungan seperti tercemarnya air dan meningkatnya level polusi (Firman 2000).

Gejala urban sprawl tidak hanya terjadi di wilayah perkotaan saja namun juga berdampak pada tingkat perkembangan wilayah di pinggiran perkotaan akibat suburbanisasi. Meskipun dalam lingkup Kawasan Metropolitan Bandung sebagian besar kawasan hinterland masih berupa kawasan tidak terbangun, di Kota Bandung dan Kota Cimahi yang merupakan pusat kota inti, sebagian besar wilayah administrasi sudah merupakan kawasan terbangun. Suburbanisasi dipicu oleh perilaku orang-orang yang memilih untuk tinggal di pinggiran kota dikarenakan harga tanah di pinggiran kota lebih murah daripada pusat perkotaan atau kota inti. Akibat yang ditimbulkan adalah meningkatnya kepadatan kawasan permukiman dengan kepadatan rendah ke pinggiran kota (urban fringe) dan kecenderungan pergeseran fungsi-fungsi perkotaan ke daerah pinggiran kota. Oleh karena itu, diperlukan upaya untuk mengetahui tingkat perkembangan wilayah, keragaman jenis penggunaan lahan, serta mengantisipasi terjadinya urban sprawl terutama dengan mengetahui faktor-faktor yang mempengaruhi pertumbuhan perkotaan dengan mempertimbangkan distribusi spasial lokasi masing-masing kecamatan di Metropolitan Bandung.

\section{METODE}

Penelitian dilaksanakan terhadap 84 kecamatan di Kawasan Cekungan Bandung Provinsi Jawa Barat yang mencakup Kota Bandung, Kota Cimahi, Kabupaten Bandung, Kabupaten Bandung Barat, dan Kabupaten Sumedang. Data yang digunakan berupa data primer dan data sekunder. Data sekunder dikumpulkan dari berbagai instansi sesuai dengan substansi yang akan dikaji, yaitu dari Badan Perencanaan Pembangunan Daerah (Bappeda) Provinsi Jawa Barat, Badan Pusat Statistik (BPS) Provinsi Jawa Barat. Data primer diperoleh dari cek lapang berupa klasifikasi lahan berupa penutupan lahan.

Dalam GWR digunakan unsur matriks pembobot W(i) yang besarnya tergantung pada kedekatan antar lokasi. Semakin dekat suatu lokasi, bobot pengaruhnya akan semakin besar. Fungsi pembobot yang digunakan untuk GWR dalam tulisan ini adalah fungsi Kernel Gaussian. Model GWR merupakan pengembangan dari model regresi global. Namun berbeda dengan regresi global yang diberlakukan secara umum di setiap lokasi pengamatan, GWR menghasilkan penduga parameter model yang bersifat lokal untuk setiap lokasi pengamatan dengan metode Weighted Least Square (WLS), yaitu :

$$
\begin{gathered}
\widehat{\boldsymbol{b}}(i)=\left(X^{\prime} W(i) X\right)^{-1} X^{\prime} W(i) Y \\
\operatorname{dimana} W(i)=\operatorname{diag}\left[W_{1}(i), W_{2}(i), \ldots, W_{n}(i)\right] \text {, dengan } 0 \leq W_{j}(i) \leq 1(i, j=1,2,3, ., \mathrm{n}) .
\end{gathered}
$$

W(i) adalah matriks pembobot spasial lokasi ke-i yang nilai elemen-elemen diagonalnya ditentukan oleh kedekatan lokasi ke-i dengan lokasi lainnya (lokasi ke-j). Semakin dekat lokasinya maka semakin besar nilai pembobot pada elemen yang bersesuaian. 
Rumus dan variable yang digunakan dalam model

$$
y_{i}=\beta_{0}\left(u_{i}, v_{i}\right)+\sum_{k=1}^{p} \beta_{k}\left(u_{i}, v_{i}\right) x_{i k}+\varepsilon_{i}
$$

Keterangan:

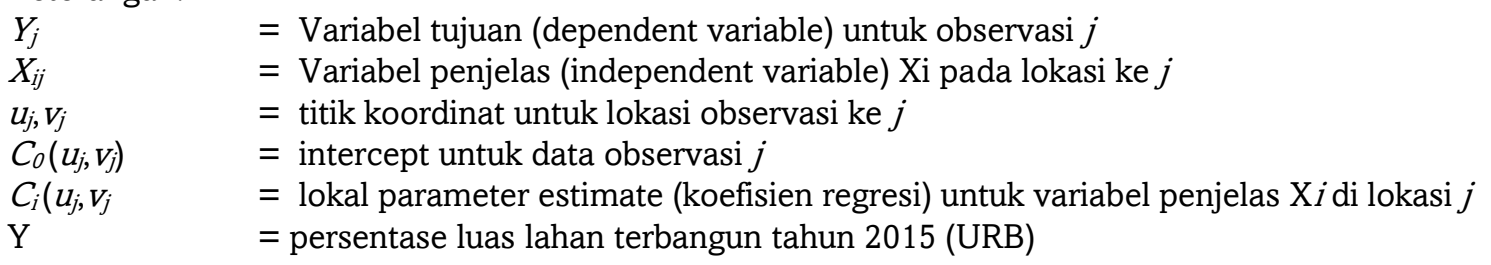

Variabel penjelas $(\mathrm{X})$ ada 6 (enam), yaitu: $\mathrm{X}_{1}=$ kepadatan penduduk (POPDEN); $\mathrm{X}_{2}$ $=$ jarak ke pusat Kota Bandung (JRKBDG); $\mathrm{X}_{3}=$ persentase luas lahan sawah $(\mathrm{PSWH}) ; \mathrm{X}_{4}=$ persentase luas lahan hutan (PHTN); $\mathrm{X}_{5}=$ jarak ke jalan tol (JRKTOL); dan $\mathrm{X}_{6}=$ Indeks Perkembangan Kecamatan (IPK).

Tabel 1. Variabel Tujuan dan Variabel Penjelas Yang Digunakan Dalam Model GWR

\begin{tabular}{lll}
\hline Variabel & Kode Variabel & Penjelasan \\
\hline $\mathrm{Y}$ & URB & Persentase luas lahan terbangun tahun 2015 (\%) \\
$\mathrm{X}_{1}$ & POPDEN & Kepadatan penduduk tahun 2015 \\
$\mathrm{X}_{2}$ & JRKBDG & Jarak ke pusat Kota Bandung $(\mathrm{km})$ \\
$\mathrm{X}_{3}$ & PSWH & Persentase luas lahan sawah tahun 2015 dibagi luas wilayah (\%) \\
$\mathrm{X}_{4}$ & PHTN & Persentase luas lahan hutan tahun 2015 dibagi luas wilayah (\%) \\
$\mathrm{X}_{5}$ & JRKTOL & Jarak ke jalan tol (km) \\
$\mathrm{X}_{6}$ & IPK & Indeks Perkembangan Kecamatan \\
\hline
\end{tabular}

\section{HASIL DAN PEMBAHASAN}

\section{Persentase Luas Lahan Terbangun}

Perkembangan wilayah di Kawasan Cekungan Bandung berpengaruh terhadap meningkatnya luas lahan terbangun. Peningkatan luas lahan terbangun dipengaruhi oleh beberapa faktor. Pada penelitian ini, dipilih enam variabel sebagai dependent variable yang diduga berpengaruh terhadap luas lahan terbangun yang terdiri dari kepadatan penduduk (X1), jarak ke pusat Kota Bandung (X2), persentase luas lahan sawah (X3), persentase luas lahan hutan (X4), jarak ke jalan tol (X5) dan Indeks Perkembangan Kecamatan/IPK (X6). Adapun independent variable $(\mathrm{Y})$ yang digunakan adalah persentase lahan terbangun tahun 2015.

Berdasarkan hasil analisis GWR, dapat dibandingkan antara variabel Y data hasil observasi (Y-observed) yang ditunjukkan pada peta (1/kiri) dengan variabel $\mathrm{Y}$ hasil prediksi model (Y-predicted) yang ditunjukkan pada peta (2/kanan). Dari kedua peta tersebut dapat dilihat bahwa pola distribusi persentase lahan terbangun area tahun 2015 hasil observasi dan hasil prediksi model tersebut hampir sama (Gambar 1). Nilai Yobserved berkisar dari 0,51 - 100, sedangkan nilai Y-predicted berkisar dari -1,57 hingga 114. Dari pola sebaran tersebut dapat diketahui bahwa persentase lahan terbangun area paling besar sebagian besar terletak di wilayah administrasi Kota Bandung yang berwarna merah. Semakin ke daerah pinggiran dan menjauhi Kota Bandung besarnya persentase luas lahan terbangun tersebut semakin semakin rendah. Sehingga beberapa kecamatan di Kabupaten Bandung dan Kabupaten Bandung Barat bagian Barat Daya yang ditunjukkan dengan warna hijau tua memiliki persentase luas lahan terbangun yang paling rendah. 

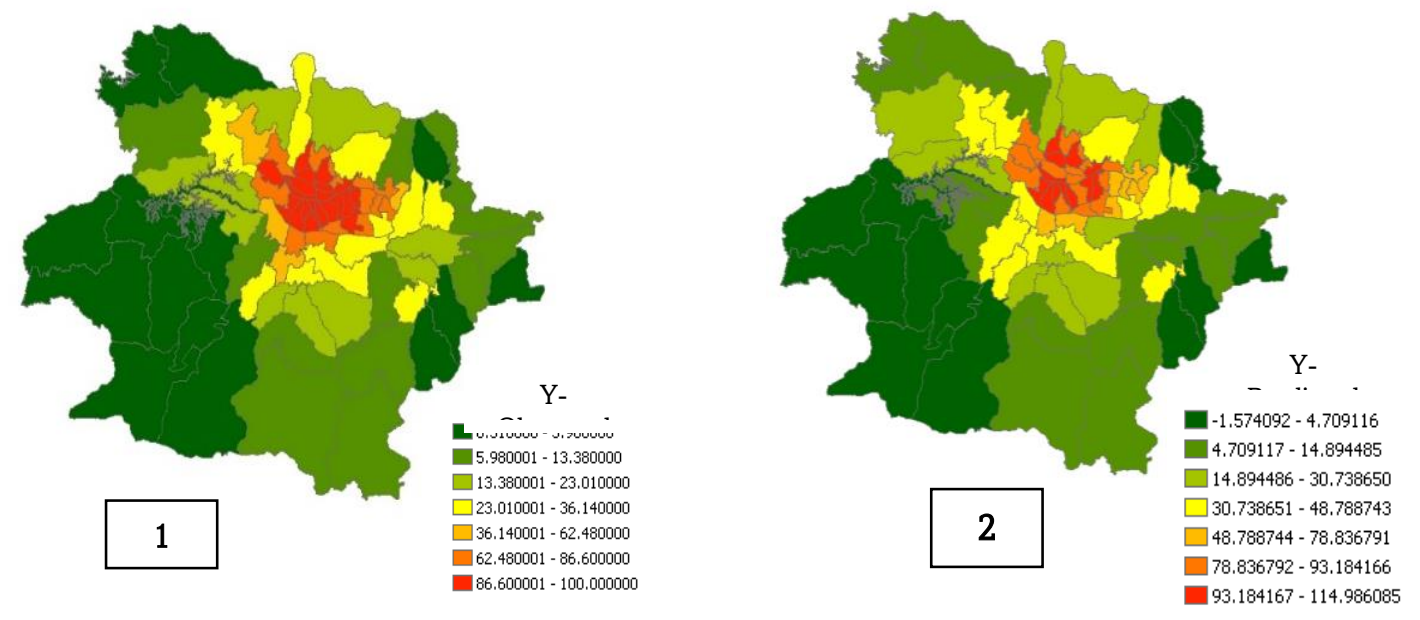

Gambar 1. Persentase lahan terbangun (1) Hasil Observasi/Y-Observed (2) Prediksi Model/Y-Predicted

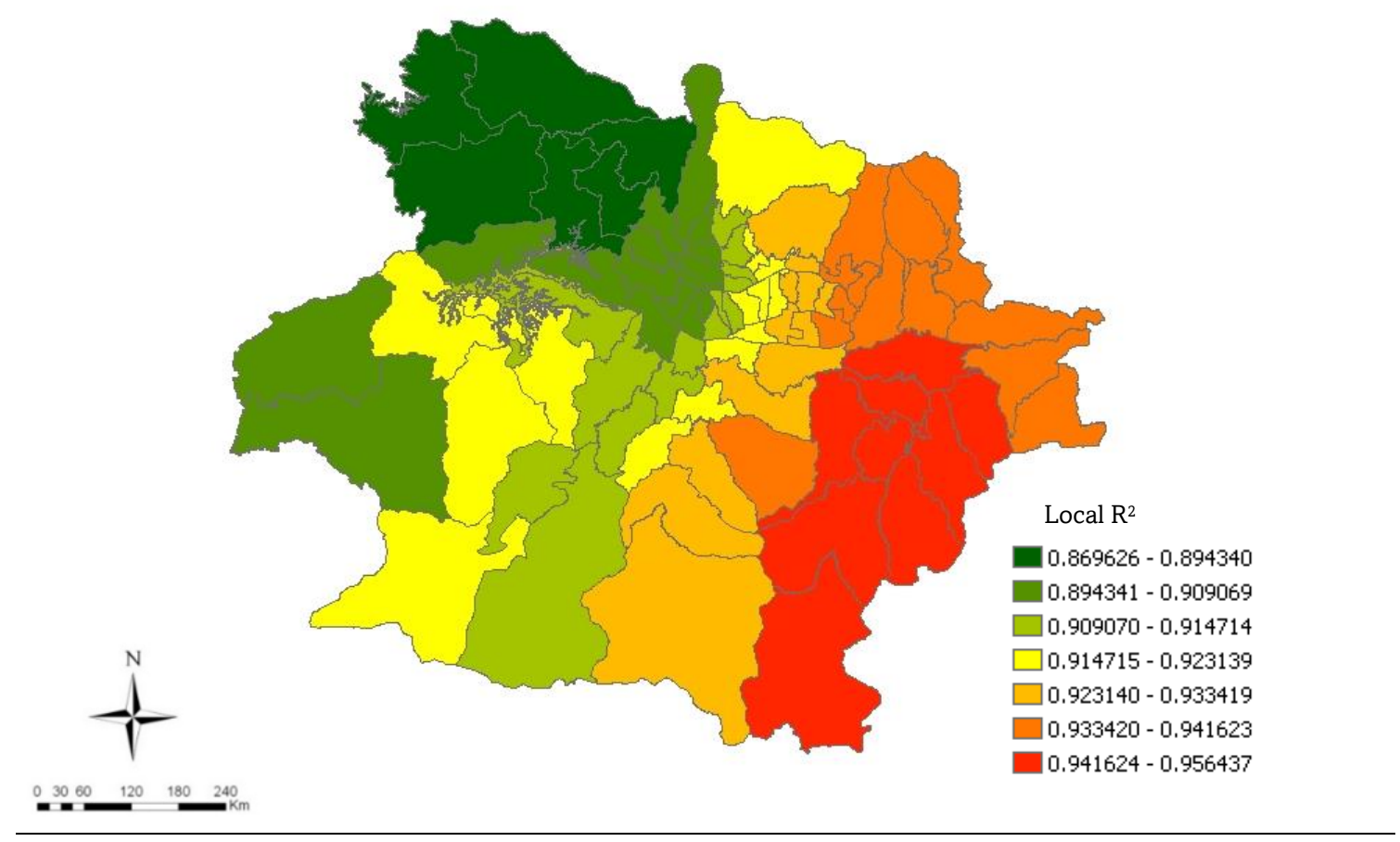

Gambar 2. Nilai Local $\mathbf{R}^{2}$ hasil analisis model GWR

Hasil analisis selanjutnya dari model Geographically Weighted Regression (GWR) adalah nilai local $\mathrm{R}^{2}$. Pada model regresi linier biasa atau yang sering dikenal dengan istilah Ordinary Least Square (OLS), nilai $\mathrm{R}^{2}$ adalah nilai koefisien determinasi, yaitu nilai yang menunjukkan fit atau tidaknya suatu model. Nilai koefisien determinasi tersebut menunjukkan seberapa besar persentase keragaman $\mathrm{Y}$ yang mampu dijelaskan oleh $\mathrm{X}$. Nilai $\mathrm{R}^{2}$ inilah yang biasanya digunakan untuk menilai kesesuaian model. Apabila dalam model OLS hanya memiliki 1 nilai $\mathrm{R}^{2}$, namun pada model GWR, setiap lokasi memiliki nilai $\mathrm{R}^{2}$ masing-masing, atau sering disebut dengan istilah nilai local $\mathrm{R}^{2}$. Pada Gambar di bawah ini, besarnya nilai $\mathrm{R}^{2}$ berbeda-beda untuk masing-masing lokasi dengan kisaran nilai antara 
0,86 hingga 0,95. Nilai local $\mathrm{R}^{2}$ paling tinggi berlokasi di bagian tenggara wilayah studi, yaitu di wilayah administrasi Kabupaten Bandung di bagian tenggara yang ditunjukkan dengan warna merah. Sedangkan local $\mathrm{R}^{2}$ paling rendah berlokasi di bagian barat laut wilayah studi, yaitu di wilayah administrasi Kabupaten Bandung Barat di bagian barat laut yang ditunjukkan dengan warna hijau (Gambar 2).

\section{Parameter Estimates (C) untuk Masing-Masing Variabel}

Hasil analisis selanjutnya dari model Geographically Weighted Regression (GWR) adalah besarnya nilai koefisien atau parameter estimates $(C)$ untuk masing-masing variabel $\mathrm{X}$ yang digunakan di dalam model. Dalam analisis ini, dipilih enam variabel $\mathrm{X}$ yang digunakan. Keenam variabel tersebut adalah: (1) $X_{1}=$ kepadatan penduduk; (2) $X_{2}=$ jarak ke pusat Kota Bandung; (3) $X_{3}=$ persentase luas lahan sawah; (4) $X_{4}=$ persentase luas hutan; (5) $\mathrm{X}_{5}=$ jarak ke jalan tol; dan (6) $\mathrm{X}_{6}=$ Indeks Perkembangan Kecamatan (IPK) (Gambar 16).

Hasil analisis GWR dalam penelitian ini menunjukkan bahwa nilai koefisien atau parameter estimate $(\mathrm{C})$ untuk variabel $\mathrm{X}_{1}$ yaitu kepadatan penduduk tersebar dengan pola seperti yang dapat dilihat pada Gambar 3 (a). Semua nilai koefisien atau parameter estimate untuk variabel kepadatan penduduk adalah positif yang berkisar antara 0,07 0,43, yang berarti bahwa meningkatnya kepadatan penduduk di suatu lokasi akan berbanding lurus dengan peningkatan persentase luas lahan terbangun area di lokasi tersebut. Wilayah yang semakin padat penduduknya akan berpotensi menyebabkan meningkatnya pembangunan lokasi-lokasi lahan terbangun area baru seperti permukiman, pabrik maupun bentuk lahan terbangun lainnya. Daerah penelitian yang berwarna merah gelap berlokasi di Kabupaten Bandung Barat sebelah barat adalah lokasi dimana pengaruh faktor kepadatan penduduk terhadap meningkatnya luas permukiman dan lahan terbangun adalah yang paling besar. Sedangkan daerah penelitian yang berwarna hijau berlokasi di Kota Bandung adalah lokasi dimana pengaruh faktor kepadatan penduduk terhadap meningkatnya luas permukiman dan lahan terbangun adalah yang paling rendah. Hal ini dikarenakan Kota Bandung yang relatif sudah padat penduduknya sehingga pertumbuhan populasi cenderung mengalami peningkatan di luar Kota Bandung, terutama di Kabupaten Bandung Barat. Laju pertumbuhan penduduk di Kota Bandung terus mengalami penurunan dari tahun 2011 hingga tahun 2016 yang ditunjukkan dalam Tabel 19. Pertumbuhan penduduk yang tinggi di daerah pinggiran kota ini terutama disebabkan oleh berlanjutnya migrasi yang berlebihan dari luar wilayah serta migrasi dari pusat kota ke pinggirannya (Pravitasari et al. 2015). Wijaya (2015) juga menyebutkan bahwa perkembangan daerah perkotaan di Metropolitan Bandung awalnya hanya berada di pusat inti kota dan sebagian terdapat di kawasan perkotaan. Namun, seiring bertambahnya waktu, perkembangannya meningkat hingga kawasan pinggiran kota diantaranya Kota Cimahi dan beberapa kecamatan di Kabupaten Bandung dan Kabupaten Bandung Barat yang berbatasan langsung dengan Kota Bandung.

Pola dan sebaran nilai parameter estimate untuk variabel $\mathrm{X}_{2}$ yaitu jarak ke pusat Kota Bandung dapat dilihat pada Gambar 3 (b). Variabel ini turut diperhitungkan sebagai salah satu driving factor yang mempengaruhi luas lahan terbangun di Metropolitan Bandung sebab aksesibilitas mempunyai pengaruh yang signifikan terhadap perkembangan permukiman. Semua nilai koefisien atau parameter estimate untuk variabel jarak ke pusat Kota Bandung adalah negatif yang berkisar antara $-1,29$ hingga $-0,19$, yang berarti bahwa meningkatnya jarak ke pusat Kota Bandung di suatu lokasi akan berbanding terbalik dengan peningkatan persentase luas lahan terbangun area di lokasi tersebut. Dengan kata lain, semakin rendah jarak suatu lokasi ke Kota Bandung, maka semakin tinggi persentase luas lahan terbangun area di lokasi tersebut. Lahan-lahan yang lokasinya dekat dengan 
Kota Bandung akan cenderung terkonversi menjadi lahan permukiman dan lahan terbangun, begitu pula sebaliknya.

Daerah penelitian yang berwarna hijau gelap berlokasi di Kabupaten Bandung Barat dan Kabupaten Bandung di bagian utara adalah lokasi dimana pengaruh faktor jarak ke pusat Kota Bandung terhadap meningkatnya luas lahan terbangun adalah yang paling rendah. Sedangkan daerah penelitian yang berwarna hijau muda berlokasi di Kabupaten Bandung adalah lokasi dimana pengaruh jarak ke pusat Kota Bandung terhadap meningkatnya luas lahan terbangun adalah yang paling tinggi. Banyaknya sistem jaringan jalan dalam suatu wilayah akan mempengaruhi nilai aksesibilitas dalam wilayah tersebut. Aksesibilitas wilayah adalah kemampuan atau keadaan suatu wilayah untuk dapat diakses oleh pihak luar baik secara langsung atau tidak langsung. Aksesibilitas yang baik akan melancarkan interaksi masyarakat antar wilayah sehingga terjadi pemerataan pembangunan.

Variabel $\mathrm{X}_{3}$ yang dimasukkan ke dalam model GWR adalah persentase luas lahan sawah. Variabel ini dimasukkan ke dalam model dengan pertimbangan salah satu jenis penggunaan lahan yang mengalami banyak perubahan atau konversi ke area terbangun adalah sawah (Pravitasari et al. 2018). Semua nilai koefisien atau parameter estimate untuk variabel persentase luas lahan sawah adalah negatif yang berkisar antara $-0,71$ hingga 0,01 . Hal ini berarti meningkatnya persentase luas lahan sawah di suatu lokasi akan berbanding terbalik dengan peningkatan persentase luas lahan terbangun di lokasi tersebut. Daerah penelitian yang berwarna hijau tua berlokasi di beberapa kecamatan di Kabupaten Bandung Barat serta beberapa kecamatan di bagian selatan Kabupaten Bandung. Lokasi tersebut merupakan lokasi dimana pengaruh faktor persentase luas lahan sawah terhadap meningkatnya luas lahan terbangun adalah yang paling rendah. Sedangkan daerah penelitian yang berwarna hijau muda berlokasi di Kota Bandung dan beberapa kecamatan di Kabupaten Bandung Barat merupakan lokasi dimana pengaruh persentase luas lahan sawah terhadap meningkatnya luas lahan terbangun adalah yang paling tinggi. Sehingga lokasi tersebut sangat rentan untuk terjadi pertambahan lahan terbangun jika sawah mengalami konversi. Sawah yang akan mengalami alih fungsi ditunjukkan dengan kondisi lahan yang sudah tidak ditanami padi dan biasanya berlokasi di pinggir jalan raya.

Menyusutnya luas lahan pertanian inilah yang diduga menjadi penyebab konversi lahan pertanian ke kawasan permukiman dan lahan terbangun. Sebagai konsekuensi logis dari pertambahan penduduk dan pembangunan ekonomi, maka terjadi perubahan alokasi sumberdaya, khususnya sumberdaya lahan sulit dihindari. Akibat tidak diperhatikannya skala prioritas alokasi penggunaan sumberdaya lahan, maka terjadi pula konflik alokasi sumberdaya lahan untuk penyediaan sumber pangan dan pembangunan sarana dan prasarana pemukiman (Irawan dan Friyatno 2005). Ruwandi et al. (2007) juga menyebutkan bahwa konversi lahan pertanian diiringi oleh penurunan tingkat kesejahteraan petani yang dapat diidentifikasi dari penurunan luas lahan milik dan luas lahan garapan, yang secara keseluruhan bermuara kepada penurunan pendapatan. Seperti contoh konversi lahan pertanian yang terjadi di daerah Bandung Utara umumnya diawali dengan penjualan lahan. Dalam jangka pendek, mungkin uang hasil penjualan tersebut akan meningkatkan kesejahteraan petani, tetapi karena umumnya sebagian besar uang hasil penjualan tersebut dibelanjakan untuk aset nonproduktif seperti membuat/rehabilitasi rumah dan membeli kendaraan, maka lahan pertanian sebagai sumber mata pencaharian utama akan semakin sempit yang dalam jangka panjang akan semakin menurunkan skala usahanya. Padahal pertanian peri-urban telah diusulkan sebagai elemen perkotaan yang penting untuk menghadapi tantangan seperti kemiskinan yang terus meningkat, kerawanan pangan, dan degradasi lingkungan yang secara khusus ditemukan di kota-kota berkembang yang berkembang pesat di dunia (Pribadi dan Pauleit 2016). 

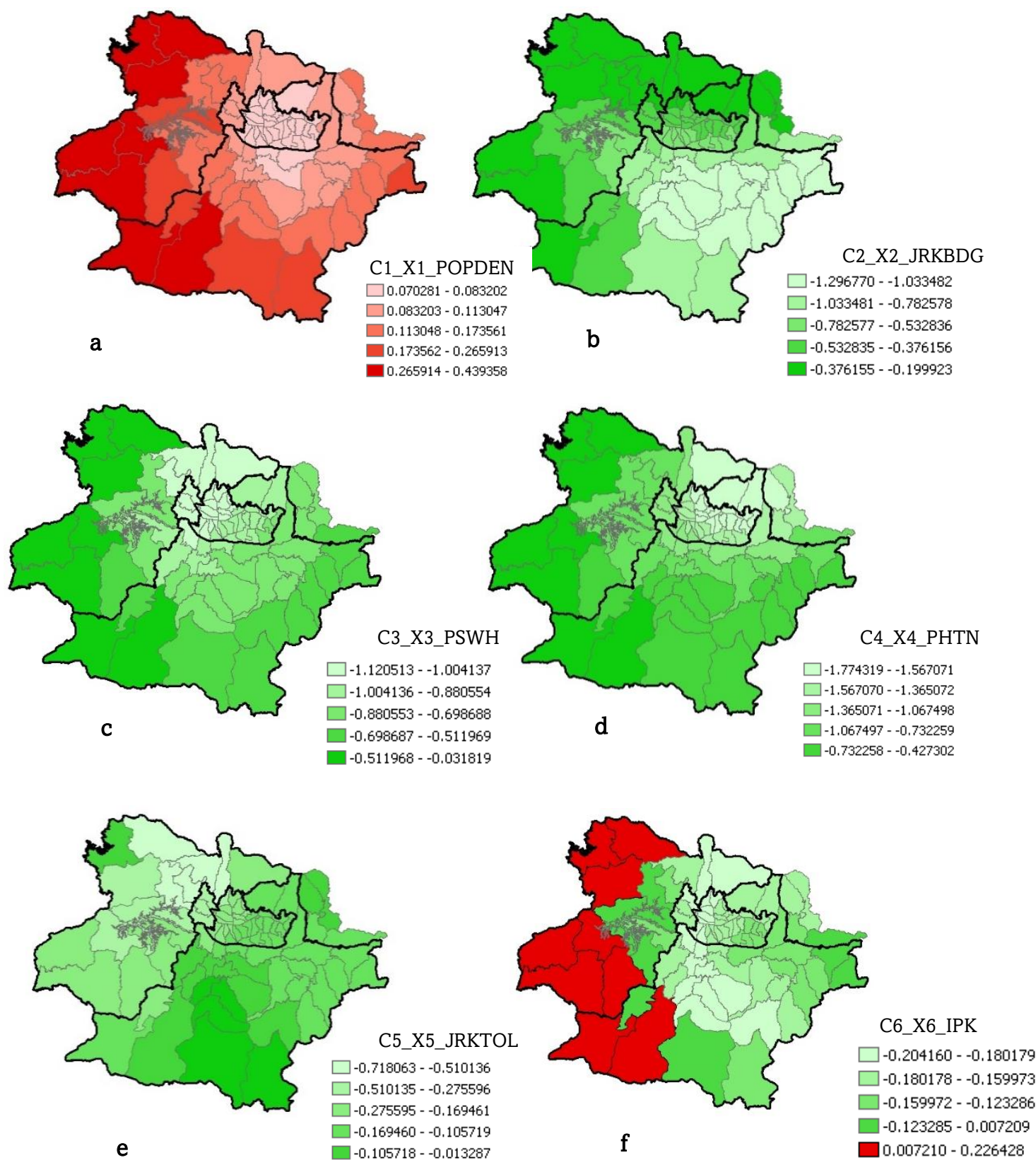

Gambar 3 Parameter estimates (C) untuk masing-masing variabel

Variabel $\mathrm{X}_{4}$ yang dimasukkan ke dalam model GWR adalah persentase luas lahan hutan. Seperti yang terjadi pada variabel persentase luas lahan sawah, pada variabel persentase luas lahan hutan semua nilai koefisien atau parameter estimate bernilai negatif yang berkisar antara $-1,77$ hingga $-0,00$. Hal ini berarti meningkatnya persentase luas lahan hutan di suatu lokasi akan berbanding terbalik dengan peningkatan persentase luas lahan terbangun di lokasi tersebut. Daerah penelitian yang berwarna hijau muda berlokasi di beberapa kecamatan di Kawasan Bandung Utara. Berdasarkan Peraturan Presiden Nomor 45 Tahun 2018, keempat kecamatan ini ditetapkan sebagai Zona L1 yang merupakan Kawasan Hutan Lindung. Kawasan Hutan ini mempunyai ketinggian paling sedikit 2.000 (dua ribu) meter di atas permukaan laut serta mempunyai tanah sangat peka terhadap erosi dengan kelerengan di atas lebih dari 15\%. Lokasi tersebut merupakan lokasi dimana 
pengaruh faktor persentase luas lahan hutan terhadap meningkatnya luas lahan terbangun adalah yang paling besar. Sedangkan daerah penelitian yang berwarna hijau tua berlokasi di beberapa kecamatan di Kabupaten Bandung Barat bagian barat. Lokasi tersebut merupakan lokasi dimana pengaruh persentase luas lahan hutan terhadap meningkatnya luas lahan terbangun adalah yang paling rendah. Wijaya (2015) menyebutkan bahwa pada tahun 2006, ekspansi penduduk di Metropolitan Bandung terlihat mulai berkembang ke arah timur, selatan dan barat. Bagian utara dibatasi oleh kawasan lindung berupa hutan, sehingga perkembangan terbatas hanya di bagian tertentu. Sedangkan pada tahun 2014, perkembangan daerah perkotaan mulai merambah ke kawasan hutan yang terdapat di bagian utara Kawasan Metropolitan Bandung.

Variabel $\mathrm{X}_{5}$ yang dimasukkan ke dalam model GWR adalah jarak ke jalan tol. Pembangunan infrastruktur jalan bebas hambatan atau jalan tol dalam sebuah negara bisa dijadikan sebagai tolok ukur untuk mengetahui sejauh mana kemajuan perekonomian sebuah negara, baik secara makro maupun secara mikro. Selain itu, industri jalan tol bisa juga dijadikan sebagai bukti kesiapan sebuah negara dalam menyongsong sebuah peradaban yang serba mudah dan serba cepat dalam setiap melakukan aktivitas (Sumaryoto 2010). Berdasarkan hasil analisis, semua nilai koefisien atau parameter estimate untuk variabel jarak ke jalan tol adalah negatif yang berkisar antara -0,71 hingga 0,01, yang berarti bahwa meningkatnya jarak ke jalan tol di suatu lokasi akan berbanding terbalik dengan peningkatan persentase luas lahan terbangun di lokasi tersebut. Dengan kata lain, semakin rendah jarak suatu lokasi ke jalan tol, maka semakin tinggi persentase luas lahan terbangun di lokasi tersebut.

Lahan-lahan yang lokasinya dekat dengan jalan tol akan cenderung terkonversi menjadi lahan permukiman dan lahan terbangun, begitu pula sebaliknya. Wilayah yang berwarna hijau muda (Gambar 3(e)) merupakan wilayah yang rentan terhadap penambahan lahan terbangun dikarenakan kedekatan dengan jarak ke jalan tol. Wilayah tersebut terdiri dari beberapa kecamatan di Kabupaten Bandung Barat bagian barat yang diantaranya terdiri dari Kecamatan Ngamprah, Kecamatan Padalarang, Kecamatan Cisarua, Kecatamatan Parongpong dan Kecamatan Cikalong Wetan. Beberapa dari kecamatan-kecamatan tersebut dilalui dan berlokasi dekat dengan beberapa jalan tol seperti Tol Purbaleunyi dan Tol Padalarang-Cileunyi. Penyediaan jaringan jalan khususnya jaringan jalan tol merupakan hal yang penting dalam mempercepat laju pembangunan karena lokasi di sepanjang tepi jalan merup akan lokasi yang strategis untuk melakukan aktivitas karena memiliki aksesbilitas yang tinggi. Selain meningkatkan aktivitas, adanya aksesibilitas jalan tol juga turut menjadi magnet bagi masyarakat luar kawasan untuk berinvestasi maupun untuk bermukim. Hal ini terbukti dengan masuknya pengembang perumahan menengah kebawah hingga menengah keatas untuk melakukan pembangunan perumahan disana.

Variabel $\mathrm{X}_{6}$ yang dimasukkan ke dalam model GWR adalah Indeks Perkembangan Kecamatan (IPK). Jika ditinjau dari kisaran nilainya, besarnya koefisien atau parameter estimate untuk variabel IPK ini mempunyai nilai yang positif hingga negatif. Nilai positif berarti menandakan bahwa besarnya pengaruh $\mathrm{X}_{6}$ berbanding lurus dengan variabel $\mathrm{Y}$ yang ditunjukkan dengan warna merah. Pengaruh positif dominan terdapat di Kabupaten Bandung Barat. Sejak dibentuk pada tahun 2007, Kabupaten Bandung Barat berupaya untuk memenuhi fasilitas penduduk dengan pembangunan sarana dan prasarana wilayah. Sehingga dapat dikatakan bahwa pembangunan fasilitas publik dan infrastruktur lainnya di Kabupaten Bandung Barat merupakan faktor pendorong terhadap peningkatan luas lahan terbangun.

Sebaliknya, apabila nilai koefisiennya negatif, menandakan bahwa besarnya pengaruh $\mathrm{X}_{6}$ berbanding terbalik dengan variabel $\mathrm{Y}$ nya. Lokasi-lokasi yang memiliki nilai parameter estimate negatif adalah daerah yang berwarna hijau muda hingga orange, yang 
terletak di bagian barat lokasi penelitian, yang menandakan bahwa pada lokasi tersebut, berkurangnya IPK akan berpengaruh signifikan pada peningkatan luas lahan terbangun di daerah tersebut. Salah satu indikator yang mendukung pengembangan wilayah kecamatan adalah ketersediaan infrastruktur dan sistem jaringan di wilayah tersebut. Ketersediaan infrastruktur seperti sarana dan prasarana dianggap sebagai faktor potensial dalam menentukan masa depan dari perkembangan suatu wilayah karena penyediaan infrastruktur memiliki kontribusi dalam meningkatkan produktivitas dan diharapkan mampu mendukung pertumbuhan ekonomi dalam jangka panjang.

\section{KESIMPULAN}

Hasil analisis GWR menunjukkan bahwa masing-masing variabel memberikan pengaruh yang berbeda di masing-masing lokasi. Variabel kepadatan penduduk berpengaruh positif terhadap peningkatan persentase luas lahan terbangun. Variabel jarak ke Kota Bandung, persentase luas sawah, persentase luas hutan, jarak ke jalan tol berpengaruh negatif terhadap peningkatan persentase luas lahan terbangun. Sedangkan pengaruh variabel IPK terhadap peningkatan persentase luas lahan terbangun bervariasi di setiap lokasi penelitian.

\section{DAFTAR PUSTAKA}

Clark D. 1998. Interdependent Urbanization in an Urban World: an Historical Overview. The Geographical Journal. 164(1): 85-95.

Firman T, Dharmapatni IAI. 1995. The Emergence Of Extended Metropolitan Regions In Indonesia: Jabotabek And Bandung Metropolitan Area. Urban and Regional Development Studies. 7(2): 167-188.

Firman T. 2000. Rural to Urban Land Conversion in Indonesia during Boom and Bust Periods. Land Use Policy. 176 (2000): 13-20.

Firman T. 2009. The Continuity and Change in Mega-urbanization in Indonesia: A Survey of Jakarta-Bandung Region (JBR) Development. Habitat International. 33: 327-339.

Irawan B, Friyatno S. 2005. Dampak Konversi Lahan Sawah di Jawa terhadap Produksi Beras dan Kebijakan Pengendaliannya. Agro Ekonomi. 23(1):1-33.

Pravitasari AE, Saizen I, Tsutsumida N, Rustiadi E, Pribadi DO. 2015. Local Spatially Dependent Driving Forces of Urban Expansion in an Emerging Asian Megacity: The Case of Greater Jakarta (Jabodetabek). Journal of Sustainable Development. 8(1): 108-119.

Pravitasari AE, Rustiadi E, Mulya SP, Setiawan Y, Fuadina LN, Murtadho A. 2018. Identifying the Driving Forces of Urban Expansion and Its Environmental Impact in Jakarta-Bandung Mega Urban Region. IOP Conf. Series: Earth and Environmental Sciences. 149: 1-10.

Pribadi DO, Pauleit S. 2016. Peri-urban Agriculture in Jabodetabek Metropolitan Area and It's Relationship with The Urban Socioeconomic System. Land Use Policy. 55: 265-274.

Rustiadi E, Panuju DR, Trisasongko BH. 2009. Environmental Impacts of Urbanization in Jabodetabek Area. Proceeding of the ICALRD-JIRCAS Workshop.

Ruswandi A, Rustiadi E, Mudikjo K. 2007. Dampak Konversi Lahan Pertanian terhadap Kesejahteraan Petani dan Perkembangan Wilayah: Studi Kasus di Daerah Bandung Utara. Jurnal Agro Ekonomi. 25(2): 207219.

Sumaryoto. 2010. Dampak Keberadaan Jalan Tol terhadap Kondisi Fisik, Sosial, dan Ekonomi Lingkungannya. Journal of Rural and Development. 1(2): 161-168.

Tarigan AKM, Sagala S, Samsura DA, Fiisabilillah DF, Simarmata HA, Nababab M. 2016. Bandung City, Indonesia. Cities. 50: 100-110.

Wijaya N. 2015. Deteksi Perubahan Penggunaan Lahan dengan Citra Landsat dan Sistem Informasi Geografis: Studi Kasus di Wilayah Metropolitan Bandung, Indonesia. Geoplanning. 2(2): 82-92.

[UN] United Nations. 2013. Urbanization trends in Asia and the Pacific. New York: United Nations of Economic and Social Commisions for Asia and The Pacific.

[UN] United Nations. 2016. The World's Cities in 2016. New York: United Nations. 